Continental J. Microbiology 1: 22 - 27, 2007.

(c) Wilolud Online Journals, 2007.

\title{
ANTIMICROBIAL SUSCEPTIBILITY PATTERNS OF BACTERIA TO SEED EXTRACTS OF RICINUS COMMUNIS: FINDINGS OF A PRELIMINARY STUDY IN NIGERIA
}

\author{
JOMBO G T A ${ }^{1}$, ENENEBEAKU M N O ${ }^{2}$ \\ ${ }^{1}$ Department of Medical Microbiology \& Parasitology, College of Medical Sciences, University of Calabar, \\ P M B 1115 Calabar, Nigeria. ${ }^{2}$ Department of Medical Microbiology, Faculty of Medical Sciences, \\ University of Jos, P M B 2084 Jos, Nigeria.
}

\begin{abstract}
Aim To ascertain the antibacterial properties inherent in seed extracts of Ricinus communis.

Procedure Dry seeds of $R$. communis were deshelled, grounded to powder and extracted both with alcohol and water using Soxhlet machine. Different concentrations of the extracts were tested against selected bacteria using diffusion method of susceptibility testing on sensitivity testing agar medium.
\end{abstract}

Results Klebsiella pneumoniae, Escherichia coli, Proteus mirabilis, Staphylococcus aureus and Enterococcus faecalis were highly susceptible to both the methanol and water extracts of the seed while Pseudomonas aeruginosa showed reduced susceptibility.

Conclusion The active antimicrobial ingredients in $R$. communis should be identified while its medicinal value to humans properly investigated in this regard.

KEY WORDS: Ricinus communis, Seed Extracts, Antimicrobial Susceptibility.

\section{INTRODUCTION}

Ricinus communis popularly called Castor bean in English is a plant that is widely distributed in virtually in all continents of the world (De Vendra, and Raghavan, 1978). Its leaves are verticulate, long-pertiolate with palmately divided laminae; flowers in terminal panicles are usually overtopped by lateral shoots; male flowers clustered at the bottom, female flowers above, with inconspicuous caduceus perianth. The fruits are globosse, triocular, soft-spiny capsules; the seeds are ovoid, compressed dorsally, thick, shiny pale-grey to almost black with dark mottling (Solaki, et al, 2006; Alm, et al, 2007; and, Iyothi, et al, 2006).

R.communis has found several daily applications in human activity (Challenger, and McCarron, 1990; and, Kinamore, et al, 1980): the oil seed is used in coating fabrics and other protective coverings (Venugopal, et al, 2006); the hydrogenated oil is utilized in the manufacture of waxes, polishes, carbon paper, candles and crayons (Hugnet-Termes, 2001; Wilcox, and Bodeker, 2004; and, Verscht, et al, 2006). It has been used with belief to cure several ailments: arthritis, asthma, boils burns, cancer, carbuncles, catarrh, chancre, cholera, cold, colic, convulsions, and 'craw-craw', to mention but a few (Lakshminaravana, and Sujatha, 2005; and, Korwar, et al, 2006).

Several biophysical properties have been associated with $R$. communis. In Jos, Nigeria, whole seeds in stat doses were found to stop pregnancy for about a year in two separate studies among volunteers (Isichei, et al, 2000; and, Das, et al, 2000). In Norway (Hekland, et al, 2000), it was found that the B chain of $R$. communis activates human complement thus boosting immunity; while findings from Sudan (Fakhri, 1989) revealed that, $R$. communis from various plant extracts were found so attain selectively various portions of the cell bodies of hippocampal neurons with defined functions. Also in India (Ilavarason, et al, 2006), its anti-inflammatory and free radical scavenging activity by inhibition of lipid peroxidation was well demonstrated. 
JOMBO G T A, ENENEBEAKU M N O: Continental J. Microbiology 1: 22 - 27, 2007.

From the microbiological stand point, there has not been much published data on $R$. communis (Choroma, et al, 1985; Villalta and Kierszenbaum, 1984; and, $\mathrm{Ng}$ and Ling, 1999) especially as concerns the antimicrobial properties of its various extracts on bacteria, fungi, viruses and parasites.

In view of the fact that bacteria have assumed an unprecedented level of antimicrobial resistance more than ever in the history of modern medicine (Jombo, et al, 2006a; Jombo, et al, 2006b; and, Jombo, et al, 2006c): the continuous search for more reliable antibiotics becomes a worthwhile and noble mission. This study was therefore set up to ascertain the antibacterial properties of the seed extracts of $R$. communis.

\section{MATERIALS AND METHOD}

Setting The study was carried out in Jos Plateau state of Nigeria between August and November 2005.

Seed Preparation Seeds of $R$. communis were obtained from Pharmacology Department of the University of Jos. These were deshelled and then crushed into fine powder using laboratory mortar and pestle.

Soxhlet Extraction The solvent used was absolute methanol. Twenty grams of the ground dry sample of the seed was placed in an extracting thimble and placed in the soxhlet apparatus. A water condenser was attached to the soxhlet apparatus at the top. The apparatus was fitted into the neck of a flask containing $250 \mathrm{mls}$ of the methanol (solvent) heated on a water bath.

The vapour from the solvent reached the soxhlet apparatus through the side tube and condensed on passing into the condenser. The condensed solvent dropped on the crude substance in the thimble and dissolved the required substance. The solution filtered through the thimble into the flask bearing the solvent. This process continued until the solvent from the thimble was colourless. Extraction was then said to be completed. This continuous extraction method extracted all the components of the plant, which were soluble in methanol. The extract was then evaporated to dryness and a light brown oily extract was collected, weighed and stored by refrigeration at temperature of $4^{0} \mathrm{C}$ for further susceptibility testing. Similar procedure was carried out for water extraction where water was used in place of methanol.

Antimicrobial Susceptibility Testing Bacteria used for the study were obtained from the Microbiology laboratory of the Jos University Teaching Hospital (JUTH), Jos. Organisms tested were: Klebsiella pneumoniae, Escherichia coli, Proteus mirabilis, Staphylococcus aureus, Pseudomonas aeruginosa and Enterococcus faecalis. Whitman no 1 filter paper was used to prepare susceptibility discs of $4 \mathrm{~mm}$ in diameter, which were sterilized in hot air oven. Commercially prepared discs of ceftriaxone (30ug) were used as positive control, which was susceptible against all the organisms, tested, while either sterile distilled water or methanol was used as negative control. The refined oil extracts obtained was either mixed with methanol or warm sterile distilled water in varying concentrations. With a fine pipette, $0.02 \mathrm{mls}$ of each concentration was impregnated with a sterile sensitivity disc; similar preparations were done with methanol and sterile distilled water. Sensitivity testing agar media were dried for 30 minutes at $37^{\circ} \mathrm{C}$ and then flooded with about $0.5 \mathrm{McFarland}$ 's broth culture equivalent of the selected organisms. Using sterile forceps, the commercially prepared ceftriaxone discs and discs impregnated with appropriate concentrations of methanol and water extracts along with the negative controls were carefully placed on the flooded agar media.

The preparation was incubated overnight at $37^{\circ} \mathrm{C}$ and the radiuses (in millimeters) of zones of inhibition were measured using vernier calipers (Scott, 1989).

Interpretation of Results The sensitivity report was interpreted as Sensitive (S), Intermediate (I) and Resistant (R) as follows:

Sensitive (S) Zone radius of inhibition wider than, equal to, or not more than $3 \mathrm{~mm}$ smaller than the positive control.

Intermediate (I) Zone radius of inhibition is more than $3 \mathrm{~mm}$ smaller than the positive control but not less than $3 \mathrm{~mm}$. 
JOMBO G T A, ENENEBEAKU M N O: Continental J. Microbiology 1: 22 - 27, 2007.

Resistant (R) No zone of inhibition or zone radius measures $2 \mathrm{~mm}$ or less.

Analysis of Results Results obtained were analysed using simple descriptive methods.

\section{RESULTS}

All the organisms tested were Resistant to both the methanol and water extracts at $5 \mathrm{mg} / \mathrm{ml}$ concentrations except Proteus mirabilis which was Intermediate against the water extract. Similarly, most organisms were Resistant to the extracts at $6 \mathrm{mg} / \mathrm{ml}$ strengths except the water extracts against Proteus mirabilis (Intermediate), and methanol extracts against Staphylococcus aureus (Intermediate).

For the $7 \mathrm{mg} / \mathrm{ml}$ concentrations, Proteus mirabilis and Staphylococcus aureus were Intermediate for both forms of extracts; Klebsiella pneumoniae Intermediate and Resistant for the methanol and water extracts respectively; Pseudomonas aeruginosa Resistant and Intermediate for the methanol and water extracts respectively. Both extracts were Resistant against Enterococcus faecalis but Intermediate and Sensitive against Escherichia coli respectively.

Most of the organisms were Intermediate to Sensitive for the $8 \mathrm{mg} / \mathrm{ml}$ extracts of both methanol and water except Enterococcus faecalis which was Resistant to both extracts as well as the methanol and water extracts of Pseudomonas aeruginosa and Klebsiella pneumoniae respectively.

Both the methanol and water extracts at $9 \mathrm{mg} / \mathrm{ml}$ strengths of the extracts were Intermediate to Sensitive against all the organisms tested, while the $10 \mathrm{mg} / \mathrm{ml}$ of both extracts were Sensitive against all except the water extracts against Pseudomonas aeruginosa which was Intermediate.

Table1Antimicrobial susceptibility patterns of bacteria to various concentrations of the seed extracts of $R$. communis.

Concentration of extracts inside disks* used (volume $=0.02 \mathrm{mls}$ )

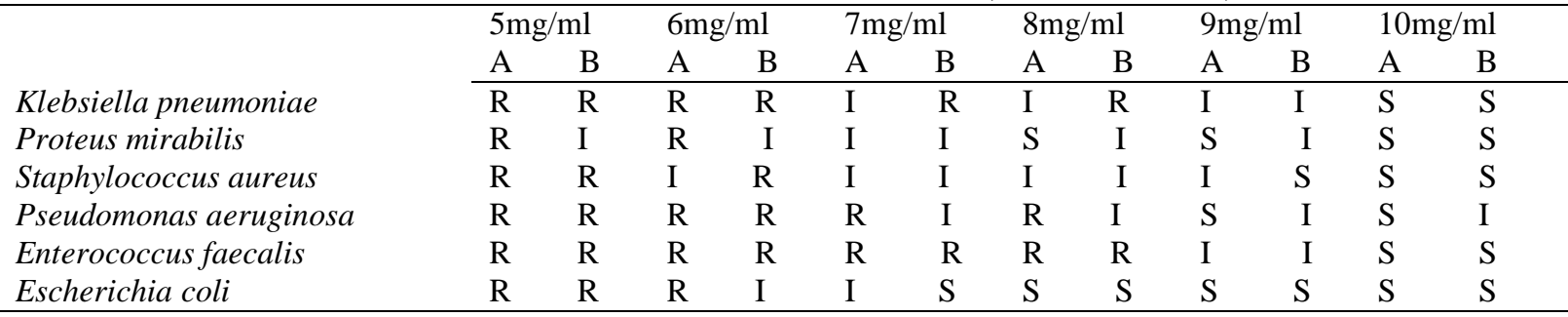

Key: A= Methanol Extracts

$\mathrm{B}=$ Water Extracts

$\mathrm{S}=$ Sensitive

$\mathrm{I}=$ Intermediate

$\mathrm{R}=$ Resistant

$*$ Disk Diameter $=4 \mathrm{~mm}$

\section{DISCUSSION}

Generally all the bacteria tested (Klebsiella pneumoniae, Escherichia coli, Proteus mirabilis, Staphylococcus aureus, Pseudomonas aeruginosa and Enterococcus faecalis) had a steady increase in susceptibility patterns from almost all resistant at $5 \mathrm{mg} / \mathrm{ml}$ concentration through intermediate/sensitive at $9 \mathrm{mg} / \mathrm{ml}$ to virtually all sensitive at $10 \mathrm{mg} / \mathrm{ml}$. This finding points to the fact that, there is a possibility to exploit the antibacterial properties inherent in the seed extract of $R$. communis for large scale medicinal uses. The finding is beneficial as it also heralds probably the emergence of a new antibiotic with such a wide spectrum of activity as found in the study being added to the existing list of them. 
JOMBO G T A, ENENEBEAKU M N O: Continental J. Microbiology 1: 22 - 27, 2007.

The active antibacterial ingredients in the Castor seed extracts should be identified and processed in possibly commercial quantities in order to seek its relevance in the current war against antimicrobial resistance. This no doubt poses a serious challenge to the modern day practice of medicine (Albertin, et al, 2002; Krishna, et al, 2004; Cuevas, et al, 2004; and, Ishikawa, et al, 2004). The fact that treatment of infections caused by organisms such as Staphylococcus aureus, Pseudomonas aeruginosa and Enterococcus faecalis are increasingly becoming difficult (Cuevas, et al, 2004; and, Ishikawa, et al, 2004) further strengthens the importance of these present findings and the need for a continuous search of antibiotics with comparative advantage.

Pseudomonas aeruginosa appeared less susceptible to the extracts compared to the other organisms. The high profile resistance of this organism against several antimicrobials in current use has severally been documented (Bouza, et al, 1999; and, Chastre, and Trouillet, 2000).

Further work should be carried out to identify the active ingredients with the antibacterial properties as well as the tolerable human dose range vis-à-vis the minimum inhibitory concentration (MIC).

In conclusion, seed extracts of $R$. communis of both ethanol and water preparations were found to be highly active against several bacteria tested. Hence, active ingredients of these seed extracts should be identified and consequently its medicinal benefits to humans exploited.

\section{REFERENCES}

Ahn Y J, Vang L, McKeon T A, Chen G Q (2007). High frequency plant regeneration through adventitious shoot formation in castor (Ricinus communis L). In vitro cellular and Developmental Biology Plant 43(1): 9-15.

Albertin M T, Benoit C, Berardi L, Berrounane Y, Boisivon A, Cahen P, et al, (2002). Surveillance of methicillin-resistant Staphylococcus aureus (MRSA) and Enterobacteriaceae producing extended-spectrum beta-lactanase (ESBLE) in Northern France: a five year multicentre incidence study. J Hosp Infect. 52(2):

107-113.

Aslani M R, Maleki M, Moluri M, Shanti K, Najjar-Nezhad V, Afshan T (2007). Castor bean (Ricinus communis) toxicosis in a sheep flock. Toxicom 2007; 49(3): 400-406.

BoeckNeto R J, Gabrielli M F R, Shibli J A, Marcantonio E, Lia R C C, Marcantonio E (2005). Histomorphometric evaluation of human sinus floor augmentation healing responses to placement of calcium phosphate or Ricinus communis polymer associated with autogenous bone. Clin Implant Dentistry \& Related Research 7(4): 181-188.

Bouza E, Garcia-Garrote F, Cercenado E, Marrin M, Diaz M S, (1999). Pseudomonas aeruginosa: a survey of resistance in 136 hospitals. Antimicrob Agents Chemother. 43(4): 981-982.

Centres For Disease Control and Prevention (CDC), (2002). Staphylococcus aureus resistant to vancomycin in United States, 2002. MMWR Morb Mortal Wkly Rep. 51(26): 565-567.

Challener K R, McCarron M M, (1990). Castor bean intoxication. Ann Emerg Med. 1177-1183.

Chastre J, Trouillet J L, (2000). Problem pathogens (Pseudomonas aeruginosa and Acinetobacter). Semin Respir Infect. 15(4): 287-298.

Choroma A, Ski L, Beat D A, Nordin J H, Pan A A, Honigberg B M (1985). Further studies on the surface saccharides in Trichomonas vaginalis strains by fluorescein- conjugated lectins. Z Parasitenkd. 71(4): 443-458. 
JOMBO G T A, ENENEBEAKU M N O: Continental J. Microbiology 1: 22 - 27, 2007.

Cuevas O, Cercenado E, Vindel A, Guinea J, Sanchez-Condi M, Sanchez-Somolinos M, et al, (2004). Evolution of the antimicrobial resistance of Staphylococcus spp. In Spain:Five nationwide prevalence studies, 1986 to 2002. Antimicrob Agents Chemother. 48(11): 4240-4245.

Das S C, Isichei C O, Okwuasaba F K, Uguru V E, Onoruvwe O, Olayinka A O, et al,(2000). Clinical pathological and toxicological studies of the effects of RICOM-1013- J of Ricinus communis var minor on women volunteers and rodents. Phytother Res. 14(1): 15-19.

De Vendra C, Raghavan G V (1978). Agricultural by-products in South-East Asia: availability, utilization and potential value. World Rev Anim Prod. 14(4): 11-27.

Fakhri Z I, (1989). Mean wheal diameter in skin tests for castor bean extracts in castor bean allergic workers of eastern Sudan. J Soc Occup Med. 39(4): 144-146.

Hetland G, Mollnes T E, Garred P (1993). The B chain but not the A chain of Ricinus communis activates human complement. Cancer Lett. 75(1): 59-63.

Huguet-Termes T (2001). New world materia medica in Spanish renaissance medicine: from scholarly reception to practical impact. Med Hist 2001; 45(3): 359-376.10.

Ikeda J, Kawakami H, Asano T, Takata K, Hirano H, Hirakawa K (1991). Distribution of glycoconjugates in gerbil hippocampal neurons-histochemical study with lectins. No To Shinkei 43(6): 539-543.

Ilavarason R, Mallika M, Venkataraman S (2006). Anti-inflammatory and free radical scavenging activity of Ricinus communis root extract. J Ethnopharmacol. 103(3): 478-480.

Ishikawa K, Miyakawa S, Tanaka T, Naide Y, Shiroki R, Hoshinaga K, (2004). The trend and susceptibility to antibacterial agents of Enterococcus spp. from urinary tract infections. Nippon Hinyokika Gakkai Zasshi. 95(1): 25-34.

Isichei C O, Das S C, Ogunkeye O O, Okwuasaba F K, Uguru V E, Onoruvwe O, et al, (2000). Preliminary clinical investigation of the contraceptive efficacy and chemical pathological effects of RICOM- 1013-J of Ricinus communis var minor on women volunteers. Phytother Res. 14(1): 40-42.

Iyothi M, Thatikunta R, Akula B (2006). Identification of castor, Ricinus communis L genotypes for rainfed conditions. J Oilseeds Research 23(2): 377-378.

Jombo G T A, Egah D Z, Ayeni J A (2006)a. Antibiotic susceptibility patterns of bacterial isolates from urine samples of acquired immunodeficiency syndrome (AIDS) patients in Jos, Nigeria. Mary Slessor J Med. 6(2): 40-49.

Jombo G T A, Ayilara A O, Bello K, Gadzama G B, Mbaawuaga E M (2006)b. Patterns of bacterial isolates from surgical sites infections at a Federal Medical Centre in North Eastern Nigeria. Mary Slessor J Med. 6(2): 59-66.

Jombo G T A, Egah D Z, Banwat E B, Ayeni J A (2006)c. Nosocomial and community acquired urinary tract infections at a Teaching Hospital in North Central Nigeria: Findings from a study of 12,458 urine samples. Nig J Med. 15(3): 230-236.

Kinamore P A, Jaeger R W, de Castro F (1980). Abrus and Ricinus ingestion: management of three cases. Clinical Toxicol. 17(3): 401-405. 
JOMBO G T A, ENENEBEAKU M N O: Continental J. Microbiology 1: 22 - 27, 2007.

Korwar G R, Pratibha G, Ravi V, Kumar D P (2006). Performance of Castor (Ricinuscommunis) and greengram (Vigna radiate) in agroforestry systems in semi-arid tropics. Indian J Agronomy 51(2): 112-115.

Krishua B V, Patil A B, Chandrasekhar M R (2004). Community-acquired methicillin- resistant Staphylococcus aureus infections in a South Indian city. Southeast Asian J Trop Med Public Health 35(2): 371-374.

Lakshminarayana M, Sujatha M (2005). Toxicity of Bacillus thuringiensis var kurstaki strains and purified crystal proteins against spodoptera litura (Fabr) on castor, Ricinus communis L. J Oilseeds Research 22(2): 433434.

$\mathrm{Ng}$ Y K, Ling E A, (1999). Emperipolesis of lymphoid cells in vagal efferent neurons following an intraneural injection of ricin into the vagus nerve in rats. Neurosci Lett. 270(3): 153-156.

Scott A. C, (1989). Laboratory control of antimicrobial therapy. In: Mackie \& McCartney Practical medical microbiology (Edited by, Collee JG, Duguid JP, Fraser AG and Marmion B P) $13^{\text {th }}$ Edn. Vol 2, United Kingdom, Edinburgh: Churchill Livingstone, 161-181pp.

Solaki R M, Bhadu V B, Jadav K V (2006). Productivity of ground nut castor intercropping system as influenced by row ratio sewing time and hybrids of Castor, Ricinus communis L. J Oilseeds Res. 23(2): 225229.

Varscht J, Tomos D, Komor E (2006). Sugar concentrations along and across the Ricinus communis L hypocotyl measured by single cell sampling analysis. Planta 224(6): 1303- 1314.

Venugopal C, Reddy G K, Reddy D S (2006). Seed yield and not returns of rainfall Castor Ricinus communis L as influenced by plant geometry and nitrogen levels. J Oilseeds Research 23(2): 353-355.

Villalta F, Kierszenbaum F (1984). Enhanced multiplication of intracellular (amastigotes) stages of Trypanosoma cruzi in vitro. J Protozool. 41(3): 487-489.

Wilcox M L, Bodeker G, (2004). Traditional herbal medicines for malaria. B M J. 329(7475): 1156-1159.

Received for Publication: 03/07/2007

Accepted for Publication: 25/08/2007

Corresponding Author:

JOMBO G T A

Department of Medical Microbiology \& Parasitology, University of Calabar Teaching Hospital, P M B 1278 Calabar, Nigeria.

E.mail- jombogodwin@yahoo.com 